\title{
Effect of nanosilver on metabolism in rainbow trout (Oncorhynchus mykiss): An investigation using different respirometric approches
}

Murray, Laura; Rennie, Michael D. ; Svendsen, Jon Christian; Enders, Eva C.

\section{Published in:}

Environmental Toxicology and Chemistry

Link to article, DOI:

$10.1002 /$ etc. 3827

Publication date:

2017

Document Version

Version created as part of publication process; publisher's layout; not normally made publicly available

Link back to DTU Orbit

Citation (APA):

Murray, L., Rennie, M. D., Svendsen, J. C., \& Enders, E. C. (2017). Effect of nanosilver on metabolism in rainbow trout (Oncorhynchus mykiss): An investigation using different respirometric approches. Environmental Toxicology and Chemistry, 36(10), 2722-2729. https://doi.org/10.1002/etc.3827

\section{General rights}

Copyright and moral rights for the publications made accessible in the public portal are retained by the authors and/or other copyright owners and it is a condition of accessing publications that users recognise and abide by the legal requirements associated with these rights.

- Users may download and print one copy of any publication from the public portal for the purpose of private study or research.

- You may not further distribute the material or use it for any profit-making activity or commercial gain

- You may freely distribute the URL identifying the publication in the public portal 


\title{
Environmental Toxicology and Chemistry
}

Environmental Toxicology

\author{
EFFECT OF NANOSILVER ON METABOLISM IN RAINBOW TROUT \\ (ONCORHYNCHUS MYKISS): AN INVESTIGATION USING DIFFERENT \\ RESPIROMETRIC APPROACHES
}

Laura Murray, Michael D. Rennie, Jon C. Svendsen, and Eva C. Enders

Environ Toxicol Chem., Accepted Article • DOI: 10.1002/etc.3827

\section{Accepted Article}

"Accepted Articles" are peer-reviewed, accepted manuscripts that have not been edited, formatted, or in any way altered by the authors since acceptance. They are citable by the Digital Object Identifier (DOI). After the manuscript is edited and formatted, it will be removed from the "Accepted Articles" Web site and published as an Early View article. Note that editing may introduce changes to the manuscript text and/or graphics which could affect content, and all legal disclaimers and ethical guidelines that apply to the journal pertain. SETAC cannot be held responsible for errors or consequences arising from the use of information contained in these manuscripts.

This article is protected by copyright. All rights reserved 
Environmental Toxicology

Environmental Toxicology and Chemistry DOI 10.1002/etc.3827

L. Murray et al.

Nanosilver effect on fish metabolism

\section{EFFECT OF NANOSILVER ON METABOLISM IN RAINBOW TROUT}

(ONCORHYNCHUS MYKISS): AN INVESTIGATION USING DIFFERENT

\section{RESPIROMETRIC APPROACHES}

Laura Murray ${ }^{1 *}$ (iD) Michael D. Rennie, ${ }^{2,3}$, Jon C. Svendsen ${ }^{4}$, and Eva C. Enders ${ }^{5}$

${ }^{1}$ Department of Biological Sciences, University of Manitoba, Winnipeg, Manitoba, Canada

${ }^{2}$ Department of Biology, Lakehead University, Thunder Bay, Ontario, Canada

${ }^{3}$ IISD-Experimental Lakes Area, Winnipeg, Manitoba, Canada

${ }^{4}$ Technical University of Denmark, Charlottenlund, Denmark

${ }^{5}$ Freshwater Institute, Fisheries \& Oceans Canada, Winnipeg, Manitoba, Canada

* Address correspondence to:

E-mail: lamurray12@gmail.com

This article contains online-only Supplemental Data

This article is protected by copyright. All rights reserved

Submitted 24 May 2016; Returned for Revision 2 August 2016; Accepted 14 April 2017

This article is protected by copyright. All rights reserved 


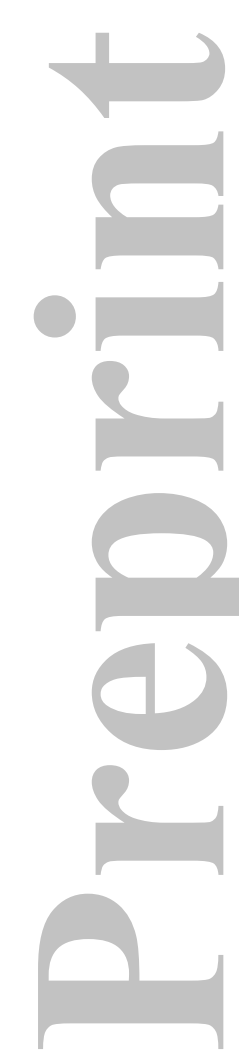

\section{Abstract}

Nanosilver (nAg) has been incorporated into many consumer products for its antimicrobial properties, including clothing and washing machines. Consequently, the potential for its release into aquatic environments is of significant concern. Documented toxic effects on fish include altered gene expression, gill damage, impaired gas exchange, as well as mortality at high $\mathrm{nAg}$ concentrations. This study reports the effects of nAg on the metabolism of Rainbow Trout (Oncorhynchus mykiss). Fish were exposed to environmentally-relevant concentrations $(0.28 \pm$ $0.02 \mu \mathrm{g} / \mathrm{L})$ and higher $(47.60 \pm 5.13 \mu \mathrm{g} / \mathrm{L})$ for $28 \mathrm{~d}$, after which their standard metabolic rate $(\mathrm{SMR})$, forced maximum metabolic rate $\left(\mathrm{MMR}_{\mathrm{f}}\right)$, and spontaneous maximum metabolic rate $\left(M_{M}\right)$ were measured. There was no effect observed in SMR, MMR $R_{f}$ or $M M R_{s}$, suggesting that $\mathrm{nAg}$ is unlikely to directly affect fish metabolism. $\mathrm{MMR}_{\mathrm{s}}$ tended to be greater than $\mathrm{MMR}_{\mathrm{f}}$ on average, and most $\mathrm{MMR}_{\mathrm{s}}$ occurred when room lighting increased. The timing of $\mathrm{MMR}_{\mathrm{f}}$ chase protocols was found to affect both $\mathrm{MMR}_{\mathrm{f}}$ and $\mathrm{SMR}$ estimates, in that chasing fish before respirometric experiments caused higher $\mathrm{MMR}_{\mathrm{f}}$ estimates and lower SMR estimates. While compounded effects involving nAg and other environmental stressors remain unknown, this study indicates that the tested range of nAg is unlikely to constrain fish metabolism. This article is protected by copyright. All rights reserved

Keywords: Ecotoxicology; Respirometry; Salmonid; Stress; Maximum metabolic rate

This article is protected by copyright. All rights reserved 


\section{INTRODUCTION}

Nanosilver is a type of nanoparticle commonly used in many consumer products for its antimicrobial properties [1]. Because many of these products include clothing, cleaning products, and washing machines [2], $\mathrm{nAg}$ is entering wastewater at an increasing rate and has significant potential to affect the aquatic environments that receive municipal waste streams. Once in the aquatic environment, $\mathrm{nAg}$ may dissolve into silver ions $\left(\mathrm{Ag}^{+}\right)$or aggregate with compounds or other $\mathrm{nAg}$ particles [3]. Concentrations of $\mathrm{nAg}$ in the aquatic environment are not well known; however, most studies estimate environmental concentrations in the nanograms per liter range [4, 5], and have been reported as high as $0.32 \mu \mathrm{g} / \mathrm{L}$ [6], and $1.4 \mu \mathrm{g} / \mathrm{L}$ [7] for some aquatic habitats.

Toxicity from $\mathrm{nAg}$ is thought to result from a combination of the effects of both the $\mathrm{nAg}$ and the $\mathrm{Ag}^{+}$it releases [8], with nAg's main mode of toxicity being through oxidative stress and silver ion's main mode being through inhibition of the $\mathrm{Na}^{+} / \mathrm{K}^{+}$ATPase pump in gill cells leading to osmoregulatory impairment [9]. Toxic effects from nAg include altered gene expression, gill damage, impaired gas exchange as well as mortality at high concentrations [10-12].

Sub-lethal effects of nAg such as changes in gene expression $[12,13]$, and impairment of gas exchange $[10,12,13]$ may affect the metabolism of fish, which encompasses all costs arising from basic bodily functions (e.g. respiration, osmoregulation), activity, and digestion/absorption/processing of food (specific dynamic action). Increased metabolic costs can lead to reduced growth $[14,15]$, fecundity [16], and potentially survival [17], all of which reflect individual fitness under the constraint of natural selection. As such, measures of metabolic rate provide a useful link between the physiological effects of contaminants and their effects on fish at both the organismal and population level $[18,19]$.

This article is protected by copyright. All rights reserved 
The objectives of this study were to investigate the effects of $\mathrm{nAg}$ on metabolism in Rainbow Trout Oncorhynchus mykiss (Walbaum 1792) through nAg exposure at environmentally relevant levels and higher. We examined potential toxic effects of nAg on standard metabolic rate (SMR), maximum metabolic rate (MMR), and aerobic scope (AS). Standard metabolic rate is defined as the minimal energy requirement of ectothermic, unstressed and resting animals at a specific temperature, which is made up of all of the basic functions of cellular metabolism such as protein synthesis and ATP turnover that keep a fish alive [20]. Maximum metabolic rate (MMR) defines the maximal aerobic metabolic rate attainable [21]. These two rates encompass the aerobic scope (AS), which describes an organisms 'scope of activity', the aerobic amount a fish can increase its metabolic activity above maintenance levels [22]. We hypothesized that sub-lethal physiological stress related to nAg exposure would potentially increase SMR (from such effects as changes in gene expression) and decrease MMR (from such effects as gill damage causing an impairment in gas exchange), thereby causing a decrease in AS.

The data set was also examined to investigate the effects of using different respirometric methods, specifically different ways to obtain MMR and the effects of changes in timing of MMR methods. This analysis is important to highlight the constraints and limitations of these methods, and how different methods have the potential to affect results. Respirometric methods are used in a growing number of studies and this analysis is relevant not just to the nAg results presented here, but to all studies that use these techniques.

This article is protected by copyright. All rights reserved 


\section{MATERIALS AND METHODS}

\section{Experimental animals}

O. mykiss were obtained from Lyndon Fish Hatcheries (New Dundee, Ontario, Canada) on February 11, $2014(\mathrm{n}=200)$, and April 29, $2014(\mathrm{n}=200)$. All fish were female diploid fish and weighed approximately $1 \mathrm{~g}$ at arrival. Fish were quarantined for one week in large (160 - 200 L) tanks, and throughout the experiment were kept at a water temperature of $14{ }^{\circ} \mathrm{C}$. Fish were exposed to a 12:12 diurnal lighting regime with gradual light changes (lights turned on and off in three stages to mimic dawn and dusk) throughout the quarantine and experiment. After quarantine, 11 fish were placed in each of the 24, $40 \mathrm{~L}$ exposure tanks, and acclimated for one week. Seven of these fish were used for cortisol and morphometric sampling at various time points (results reported in Murray et al. [23]), and 4 fish from each tank were used in the respirometric experiments, for a total of 94 fish included in respirometric experiments (there were two mortalities, bringing the total down from the 96 allocated). There were also several issues with equipment failure and deviations from protocol that lowered the number of fish included to 80 for $\mathrm{SMR}, 93$ for $\mathrm{MMR}_{\mathrm{f}}, 89$ for $\mathrm{MMR}_{\mathrm{s}}, 79$ for $\mathrm{AS}_{\mathrm{f}}$, and 80 for $\mathrm{AS}_{\mathrm{s}}$. At the time that respirometric experiments were initiated, fish weighed on average $2.91 \pm 1.14 \mathrm{~g}$.

\section{Exposure experiment}

Nanosilver exposure was achieved through a flow-through set-up, where a peristaltic pump transported nAg solution to the tanks. There were two exposure trials, with treatments comprising of (1) a control, and nominal exposure concentrations of $1 \mu \mathrm{g} / \mathrm{L}$, and a $200 \mu \mathrm{g} / \mathrm{L}$ in the first trial and (2) a control, and nominal exposure concentrations of $300 \mu \mathrm{g} / \mathrm{L}$, and a $600 \mu \mathrm{g} / \mathrm{L}$ in the second trial. Four replicate exposures were conducted for each treatment, giving 24 total exposures over both trials. However, it was observed that measured $\mathrm{nAg}$ concentrations were

This article is protected by copyright. All rights reserved 
much lower than nominal concentrations and quite variable, and that concentrations within the higher exposure tanks $(200,300$, and $600 \mu \mathrm{g} / \mathrm{L}$ nominal) overlapped and were not significantly different [23]. As a result, respirometric data for these exposure groups were combined into a single group (called "high"). Therefore, for statistical analysis, we considered three treatment levels over both trials: the controls ( $\mathrm{C}$, from both trials), a low (L, $1 \mu \mathrm{g} / \mathrm{L}$ nominal concentration from trial 1 , mean exposure concentration $=0.28 \pm 0.02 \mu \mathrm{g} / \mathrm{L})$, and a high exposure $(\mathrm{H}, 200 \mu \mathrm{g} / \mathrm{L}$ nominal concentration from trial 1 , and 300, and $600 \mu \mathrm{g} / \mathrm{L}$ nominal concentrations from trial 2 , mean exposure concentration $=47.61 \pm 5.13 \mu \mathrm{g} / \mathrm{L})$.

Exposures were conducted for $28 \mathrm{~d}$ prior to respirometric experimentation. Ag concentrations in randomly selected exposure tanks were taken every $4 \mathrm{~d}$. Detailed methods of Ag measurements in water are described in Murray et al. [23]. Briefly, total Ag was analyzed by inductively coupled plasma-mass spectrometry (ICP-MS; XSeries 2; Thermo Scientific).

Concentrations of $\mathrm{nAg}$ in comparison to ionic $\mathrm{Ag}$ were analyzed by collecting water samples in centrifugal filter tubes (Amicon® Ultra-3K; EMD Millipore, Etobicoke, Ontario, Canada), and then centrifuging samples to separate the retentate from the dissolved fraction. The two fractions were then analyzed by ICP-MS to determine the total Ag in the retentate (nAg) and the dissolved fraction (ionic Ag).

\section{Respirometric experiments}

Respirometric experiments were conducted at the end of the exposures on four fish from each of the 24 exposure tanks that had not been fed for at least $24 \mathrm{~h}$. Three metabolic rates were measured for each fish; standard metabolic rate (SMR), forced maximum metabolic rate $\left(\mathrm{MMR}_{\mathrm{f}}\right)$, and spontaneous maximum metabolic rate $\left(\mathrm{MMR}_{\mathrm{s}}\right)$. Estimation of SMR and MMR were estimated from fish held in respirometric chambers for a $24 \mathrm{~h}$ period, whereas $\mathrm{MMR}_{\mathrm{f}}$ was

This article is protected by copyright. All rights reserved 
estimated as the maximal respiration after a chase trial (see below).

Four cylindrical chambers $($ with length $=12.3 \mathrm{~cm}$, diameter $=3.3 \mathrm{~cm}$, and volume $=92 \mathrm{~mL}$ each) were installed in a $400 \mathrm{~L}$ tank with recirculating water. Each chamber was sealed and monitored for oxygen using an oxygen probe. Temperature was kept at $14 \pm 0.1{ }^{\circ} \mathrm{C}$ with water baths and water was kept oxygenated and mixed with air stones and pumps. Fish were exposed to the same 12:12 diurnal cycle as for the exposure experiment (with gradual light changes) and shielded from any external stimuli with a dark curtain draped around all edges of the tank.

Activity in the room where experiments were conducted was also minimized. Equipment in the tank was kept to a minimum to reduce bacterial respiration and potential adhesion of nanoparticles. Oxygen probes were calibrated every week or when inconsistencies in oxygen measurements were observed. Before each respirometric trial, nAg stock solution was added to the tank to match nominal exposure concentrations and similar to exposure experiments, water samples were taken near the end of the experiment to ascertain actual Ag concentrations. Like the exposures, total silver measured in respirometric tanks was also lower than nominal [24]. To minimize background bacterial respiration and contamination of $\mathrm{nAg}$ between experiments, the tank was drained and all surfaces cleaned and flushed repeatedly with water between experiments. After respirometric experiments were completed, the fish were measured, weighed, and euthanized by cervical dislocation. Muscle tissue was also taken for determination of total silver concentration.

Oxygen consumption rates were measured by automatic intermittent-flow respirometry [25] using a AutoResp system (Loligo Systems, Tjele, Denmark). In the respirometric system, water was pumped continuously by a flow pump (Eheim Universal Hobby Pump 1046, Deizisau, Germany) from each chamber to the fiber optic probe (PreSens, Regensburg, Germany) and back

This article is protected by copyright. All rights reserved 
into the chamber. Each respirometric cycle lasted for 8.5 - 9 min and consisted of a flushing period of $3 \mathrm{~min}$ where water in the respirometer was renewed with water from the holding tank, a 1 min wait period where the respirometer was closed but no oxygen concentration measurements were taken, and a 5.5 - 6 min measure period when oxygen concentrations were measured. The measurement period was shortened to $5.5 \mathrm{~min}$ to ensure that oxygen conditions remained normoxic in the chambers. The rate of decline in oxygen concentration during this period permitted estimation of oxygen consumption rate $\left(\dot{M} \mathrm{O}_{2}\right)$ [26].

For each respirometric trial, background $\dot{\mathrm{M}} \mathrm{O}_{2}$ (i.e. no fish inside the respirometer chamber) from before and after each respirometric trial were measured with 20 min measure periods for each respirometer, averaged, and the average subtracted from all whole fish oxygen consumption rate $\left(\mathrm{mgO}_{2} / \mathrm{h}\right)$ estimates [27]. Individual $\dot{M} \mathrm{O}_{2}$ estimates with an $r^{2}$ lower than 0.9 were determined to reflect poor linear estimates of oxygen consumption rates [28] and were eliminated. Estimates of $\dot{M} \mathrm{O}_{2}$ in the respirometers with low $\mathrm{O}_{2}$ concentrations in the respirometers were also eliminated to ensure fish were not oxygen-limited $(<73.1 \%$ air saturation or approximately $15.2 \mathrm{kPa}$ as per [29]). This data processing resulted in the removal of a small amount of $\dot{\mathrm{M} O}{ }_{2}$ measurements $(0.08 \%$ of measurements excluded due to low oxygen concentration in the respirometric chamber, $0.16 \%$ of measurements not used due to low $r^{2}$, for a total of $0.24 \%$ of the 13,120 measurements removed from the estimation of oxygen consumption rates).

Subsequently, mass-specific oxygen consumption rates were calculated as

$$
\operatorname{spec}_{\operatorname{MO}}=\frac{M O_{2}}{M^{b}}
$$

This article is protected by copyright. All rights reserved 
where ${ }_{\text {spec }} \dot{M} \mathrm{O}_{2}$ is the mass-specific oxygen consumption rate $\left(\mathrm{mg} \mathrm{O}_{2} / \mathrm{kg} / \mathrm{h}\right), \mathrm{M}$ the fish body mass $(\mathrm{kg})$, and $b$ is the mass exponent adjustment. For $\mathrm{MMR}_{\mathrm{f}}, b=0.88$, but was 1 for all other respirometric rates (description of mass exponent adjustment estimation can be found in Estimation of mass-adjusted metabolic rates section below).

$S M R$ and $M M R_{s}$

SMR was estimated as the mean of the 10 lowest observed $\dot{M} \mathrm{O}_{2}$ estimates during the $24 \mathrm{~h}$ experiment [30,31]. This method was chosen after estimating SMR using various methods [32], and finding that it best represented the data when examining $\dot{M} O_{2}$ plots and comparing the SMR estimates achieved with the various methods to the position of the horizontal band of low $\dot{\mathrm{M}} \mathrm{O}_{2}$ values. $\mathrm{MMR}_{\mathrm{f}}$ was defined as the single highest $\dot{\mathrm{M}} \mathrm{O}_{2}$ of the three estimates observed immediately after the chase procedure [33]. $\mathrm{MMR}_{\mathrm{s}}$ was calculated as the highest single $\dot{\mathrm{M}} \mathrm{O}_{2}$ observed during the $24 \mathrm{~h}$ experiment (excluding $\mathrm{MMR}_{\mathrm{f}}$ measurements) ([similar to [31]). Aerobic scopes between both SMR and $\mathrm{MMR}_{\mathrm{f}}\left(\mathrm{AS}_{\mathrm{f}}\right)$, and $\mathrm{SMR}$ and $\mathrm{MMR}_{\mathrm{s}}\left(\mathrm{AS}_{\mathrm{s}}\right)$ were calculated by subtracting the SMR from the $\mathrm{MMR}_{\mathrm{f}}$ and $M M R_{\mathrm{s}}$, respectively [34]. $M M R_{f}$

To estimate $M M R_{f}$, one fish at a time was placed in a circular bucket and exhausted through a standardized 5 min manual chase method; 1 min chase, 3 min turning the fish over, and 1 min holding the fish out of water $[35,36]$. At the end of this 5 min chase, fish were not capable of burst swimming, a sign of exhaustion [37]. Immediately after chasing, fish were placed into a respirometric chamber to measure maximum metabolic rate. For a subset of fish (the first three tanks tested out of 24 ), $M_{\mathrm{fMR}}$ was conducted at the end of the SMR measurements. Having observed higher rates of metabolism $\left(\mathrm{MMR}_{\mathrm{s}}\right)$ during SMR trials than observed during $\mathrm{MMR}_{\mathrm{f}}$ (see results), the protocol was then changed to test $\mathrm{MMR}_{\mathrm{f}}$ at the

This article is protected by copyright. All rights reserved 
beginning of the respirometric trial, in an attempt to obtain higher $\mathrm{MMR}_{\mathrm{f}}$ measurements by potentially capturing the immediate stress of transfer to a novel environment (the respirometric chamber) in addition to the chase methods. The influence of the timing of $\mathrm{MMR}_{\mathrm{f}}$ estimation on other respirometric variables was evaluated to ensure this change in methods did not influence results.

\section{Estimation of mass-adjusted metabolic rates}

In order to mass-adjust metabolic rates for the size of fish appropriately, it was first determined whether rates were isometric with body size [15] by examining $\log _{10}$-transformed relationships between each rate with $\log _{10}$-transformed body mass, including treatments $\mathrm{C}$ (control), L (low), and $\mathrm{H}$ (high) as a grouping variable. For each rate, differences in slopes among treatments were examined and in all but one case, slopes were not significantly different among treatments (test for heterogeneity of slopes, all $p>0.05$ ). In the case of $\mathrm{MMR}_{\mathrm{f}}$, a single outlier in the L treatment with high leverage resulted in a more elevated slope compared with the other two treatments (test for heterogeneity of slopes, $p=0.045$ ). Upon removal of this single outlier value, slopes were not significantly different among treatments $(p=0.055)$, and analysis proceeded without the outlier.

Next, for each metabolic rate, analysis of covariance (ANCOVA) was used to determine a common slope value for instances where differences existed among treatments in the relationship between $\log _{10}$ (metabolic rate) and $\log _{10}$ (body mass). For both SMR and MMR effect of treatment was not significant (ANCOVA, SMR: $F_{1,2}=0.34, p=0.71 ; \mathrm{MMR}_{\mathrm{f}}: F_{1,2}=$ $0.20, p=0.82$ ). In the case of $M_{M R}$, treatment was a significant effect in the model (ANCOVA: $F_{1,2}=3.61, p=0.03$ ), with the high treatment significantly lower by weight than the control (Tukey's HSD, $p=0.04$ ). In this case, the common slope from the ANCOVA was taken and

This article is protected by copyright. All rights reserved 
evaluated against a value representing isometry (slope of 1) using a one sample $t$-test.

Where there was no significant treatment effect in the ANCOVA models, treatment was ignored and the slope of each metabolic rate was estimated with body mass for all observations (each $\log _{10}$-transformed). In all but one case, the slope of each rate was not significantly different from 1 (one sample $t$-test, SMR $t_{78}=1.50, p=0.54$ MMR $_{\mathrm{s}} t_{86}=-0.56, p=0.49$ ). For these rates, it was concluded that metabolic rates were isometric with a mass exponent equal to 1 . In the case of $\mathrm{MMR}_{\mathrm{f}}$, the slope of the $\log$-log relationship of mass-relative rates against body size resulted in a slope of 0.88 , which was significantly different from a slope of 1 (one sample $t$-test, $\mathrm{t} 90=-1.72, p=0.045)$. Residual plots of the models were examined for normality and homogeneity among treatments and in all cases were found to meet assumptions. Relationships between metabolic variables and fish body mass are graphed in Supplemental Data Figure S1. Statistical analysis

Analyses were conducted in R version 3.1.3 [38]. Respirometric data $\left(\mathrm{SMR}, \mathrm{MMR}_{\mathrm{f}}\right.$, $\mathrm{MMR}_{\mathrm{s}}, \mathrm{AS}_{\mathrm{f}}, \mathrm{AS}_{\mathrm{s}}$ ) were analyzed using a mixed-effect model (lmer). The full model tested for effects was:

$$
\text { Respirometry variable }=\text { Treatment }+ \text { Tank }+ \text { Chamber }+ \text { Time of } M M R_{f}(2)
$$

where treatment was a fixed effect and tank, chamber, and timing of $\mathrm{MMR}_{\mathrm{f}}$ (conducting $\mathrm{MMR}_{\mathrm{f}}$ procedure before or after SMR experiments) were random effects. In order to determine the significance of nanosilver exposure on O. mykiss metabolic rates, log-likelihood tests were used to compare the full model (above) to a reduced model (the full model without the Treatment

This article is protected by copyright. All rights reserved 
effect).

The effect of timing of $\mathrm{MMR}_{\mathrm{f}}$ chase procedure on respirometric variables was analyzed using a Welch's two sample $t$-test. For $\mathrm{MMR}_{\mathrm{f}}$, a significant difference was found between trial controls (likely due to the change in timing of $\mathrm{MMR}_{\mathrm{f}}$ procedure). Therefore, trial was included in these models as a random effect. No significant differences were found for all other respirometric variables between the controls of each trial (ANOVA, all $p>0.05$ ), consequently, controls were combined into a single treatment and trial was not considered a factor in the analysis. Residual plots of the models were examined for normality and homogeneity among treatments and in all cases were found to meet assumptions. Where appropriate, post-hoc analyses were conducted with a Tukey's HSD test.

\section{RESULTS}

Exposure concentrations of Ag

Most of the Ag measured in the exposure tanks was in particulate form (nAg), with only $0 \%$ to $0.18 \%$ in ionic form $\left(\mathrm{Ag}^{+}\right.$; average $0.05 \%$ ionic). Concentrations of total $\mathrm{Ag}$ were lower than nominal and quite variable, ranging from 0.18 to $0.38 \mu \mathrm{g} / \mathrm{L}$ in the $\mathrm{L}$ treatment, and 4.46 to $159 \mu \mathrm{g} / \mathrm{L}$ in the $\mathrm{H}$ treatment (Supplemental Data, Table S1). Additional details on concentrations of total Ag can be found in Murray et al. [23].

\section{Effects of $n A g$ on metabolic rates}

The mixed effects analysis of metabolic rates revealed no difference in SMR among nAg treatments, which had an overall mean of $119 \mathrm{mg} \mathrm{O} / \mathrm{kg} / \mathrm{h}$ (Figure $1 \mathrm{~A}$, Table 1 ; log-likelihood test, $\left.\chi^{2}(d f=2)=2.682 p=0.262\right)$. There was also no difference between treatments for $\mathrm{MMR}_{\mathrm{f}}$, which had an overall mean of $470 \mathrm{mg} \mathrm{O} / \mathrm{kg} / \mathrm{h}$ (Figure $1 \mathrm{~B}$, Table 1 ; log-likelihood test, $\chi^{2}(d f=2)=$ 0.132, $p=0.936$ ), or $\mathrm{MMR}_{\mathrm{s}}$, which had an overall mean of $495 \mathrm{mg} \mathrm{O}_{2} / \mathrm{kg} / \mathrm{h}$, although the high This article is protected by copyright. All rights reserved 
treatment appeared lower than other treatments (Figure 1C, Table 1; log-likelihood test, $\chi^{2}(d f=2)$ $=5.279, p=0.071)$ and was significantly lower when mass-adjusted rates were compared with mass as a covariate (see methods). Finally, no difference by treatment was found for either $\mathrm{AS}_{\mathrm{f}}$, with an overall mean of $357 \mathrm{mg} \mathrm{O} / \mathrm{kg} / \mathrm{h}$ (Figure 1D, Table 1; log-likelihood test, $\chi^{2}{ }_{(d f=2)}=$ $0.081, p=0.960$ ), or $\mathrm{AS}_{\mathrm{s}}$ with an overall mean of $376 \mathrm{mg} \mathrm{O} / \mathrm{kg} / \mathrm{h}$ (Figure 1E, Table 1; $\log$ likelihood test, $\left.\chi_{(d f=2)}^{2}=3.409, p=0.182\right)$.

\section{Maximum metabolic rates}

$\mathrm{MMR}_{\mathrm{s}}$ was higher than $\mathrm{MMR}_{\mathrm{f}}$ for $59 \%$ of the 87 measurements, with $\mathrm{MMR}_{\mathrm{f}}$ being on average $95 \%$ of $\mathrm{MMR}_{\mathrm{s} .}$ Interestingly, $\mathrm{MMR}_{\mathrm{s}}$ most often coincided with the change in the room lighting, particularly when the room lighting increased in the morning (63.3\% of $\mathrm{MMR}_{\mathrm{s}}$ measurements). An example of the typical pattern of $\dot{M} \mathrm{O}_{2}$ in the experiments can be seen in Figure 3, with the timing of lighting increasing and decreasing marked.

$\mathrm{MMR}_{\mathrm{f}}$ and $\mathrm{AS}_{\mathrm{f}}$ were found to be higher if the $\mathrm{MMR}_{\mathrm{f}}$ chase procedure was conducted before the respirometric experiment (Figure 4; two-sample $t$-test; $\mathrm{MMR}_{\mathrm{f}}, t_{11.01}=-3.015, p<$ $\left.0.012 ; \mathrm{AS}_{\mathrm{f}}, t 8.029=-5.738, p<0.001\right)$. The mean for $\mathrm{MMR}_{\mathrm{f}}$ when fish were chased at the beginning of the respirometric trial was $481.44 \pm 10.60(\mathrm{n}=82)$ and $378.49 \pm 32.45(\mathrm{n}=10)$ when chased after. The mean $\mathrm{AS}_{\mathrm{f}}$ when fish were chased before the trial was $368.54 \pm 11.91(\mathrm{n}=$ 73) and $220.36 \pm 22.91(n=6)$ when chased after. SMR was found to actually be lower if fish were chased before the trial (Figure 4; t-test; $t 77.812=3.117, p<0.003$ ). The mean SMR when chased before the respirometric trial was $116.43 \pm 2.88(\mathrm{n}=73)$, and $144.44 \pm 11.22(\mathrm{n}=7)$ when chased after. No significant difference was found for spontaneous metabolism $\left(\mathrm{MMR}_{\mathrm{s}}\right.$ and $\mathrm{AS}_{\mathrm{s}}$ ) based on the timing of chase procedure.

This article is protected by copyright. All rights reserved 


\section{DISCUSSION}

\section{Nanosilver effects on metabolism}

Once random effects were accounted for, results showed no significant effect of nAg on metabolic variables of SMR and $\mathrm{MMR}_{\mathrm{f}}$ in $O$. mykiss following $28 \mathrm{~d}$ of exposure. Measures of $\mathrm{MMR}_{\mathrm{s}}$ were significantly depressed relative to controls using body size as a covariate but this relation became insignificant once random effects were accounted for. These results as well as results from other studies seem to suggest that metabolic rate may be largely insensitive to $\mathrm{nAg}$ exposure, even at very high exposure concentrations. Similar to our results, Bilberg et al. [10] did not observe an effect of nAg on SMR of Eurasian Perch (Perca fluviatilis) at nominal concentrations from 63-300 $\mu \mathrm{g} / \mathrm{L}$ over $24 \mathrm{~h}$, but nAg did decrease hypoxia tolerance at $300 \mu \mathrm{g} / \mathrm{L}$ exposure. In the same study, bulk silver (in the form of silver nitrate) at a nominal concentration of $386 \mu \mathrm{g} / \mathrm{L}$ increased SMR and decreased hypoxia tolerance. The present results confirm this insensitivity over a similar nominal exposure concentration, but over a more biologically relevant time period when evaluating potential risk to aquatic ecosystems ( $28 \mathrm{~d}$ in this study versus 24 h). Similarly, in Zebrafish (Danio rerio) embryos, no effect of nAg on the metabolic rate was observed when exposed for 24 - 48 h to very high levels of $n A g(20,000-140,000 \mu \mathrm{g} / \mathrm{L})$ [39].

In parallel with the present study, Murray et al. [23] examined plasma cortisol and nAg accumulation in $O$. mykiss. Fish exposed to $\mathrm{nAg}$ for $28 \mathrm{~d}$ showed a significant cortisol (stress) response to nAg exposure, and were found to have accumulated significant Ag in muscle tissue at the highest exposures. These significant direct cortisol effects are in contrast to the general lack of an effect of nAg on SMR in this and other studies. Other studies have reported significant correlations between cortisol elevation and SMR [40, 41]. In addition other studies have shown

This article is protected by copyright. All rights reserved 
an effect of nAg exposure on metabolism when fish were under additional stress (hypoxia); potentially due to gill damage that nAg has been observed to cause in fish $[11,13]$. This study did reveal some evidence that $\mathrm{MMR}_{\mathrm{S}}$ may be depressed at a high concentration of $\mathrm{nAg}$, which may indicate some effect of $\mathrm{nAg}$ on maximum metabolic rates, but only at very high levels of exposure unlikely to be encountered in natural systems.

It is possible that the inability to detect significant changes in metabolic rates may be due to adaptation to chronic exposures of the contaminant under study. Though to our knowledge, no other studies have been conducted on the effects of other nanoparticles on fish metabolism, a variety of studies have analyzed the effect of ionic metals on metabolic rate where a phenomenon of increasing metabolic insensitivity with exposure time has been observed. For example, lead $(\mathrm{Pb})$ decreased $\mathrm{MMR}_{\mathrm{f}}$ during acute exposure $(24 \mathrm{~h})$, but not in chronic exposures of 33-57 d in Fathead Minnow (Pimphales promelas), indicating that fish were able to recover from the effects of $\mathrm{Pb}$ on metabolism [42]. It is possible that this same phenomenon of recovery with chronic exposure to a contaminant may be at work in this study, and may be why no significant effect on metabolic rates was seen after $28 \mathrm{~d}$, while a significant effect on metabolism was observed when fish were under additional stress (hypoxia) following their shorter (24 h) exposure [10]. A pattern of recovery of other toxic effects from nAg over time also supports this. For example, gill epithelial proliferation was more distinct at $14 \mathrm{~d}$ exposure in comparison to 35 $d$ [13] and altered gene expression was often greater at 7 or $21 \mathrm{~d}$ exposure versus $28 \mathrm{~d}$ [12]. Short term effects could be important in natural settings where intermittent decreases in physiological performance could play a role in fish reproduction and survival, although this hypothesis remains to be tested. However, such intermittent effects are not representative in all cases of metal exposure; the effect of chronic aluminum (Al) on O. mykiss in acidic water exposed for $36 \mathrm{~d}$ was

This article is protected by copyright. All rights reserved 
found to decrease $\mathrm{MMR}_{\mathrm{f}}$ and $\mathrm{AS}_{\mathrm{f}}$ by approximately half, and there was a trend for increased SMR [43]. These studies do however generally support the hypothesis of an increase in SMR and decrease in MMR due to contaminant exposure, though this pattern appears to depend on exposure time (chronic versus acute) [20].

Another potential challenge in detecting an effect of nanosilver exposure on SMR is the observation that the respirometric procedure appears to be inherently stressful, indicated by elevated cortisol levels in fish that were involved in respirometric experiments in comparison to fish that were not [44]. An elevated metabolic response due to respirometry may make more subtle differences in SMR due to contaminant exposure more difficult to detect. This potential elevated standard metabolism may not affect $\mathrm{MMR}_{\mathrm{s}}$, but elevated SMR would certainly affect AS estimates.

Comparison of methods in estimating maximum metabolic rates

$\mathrm{MMR}_{\mathrm{f}}$ was lower than $\mathrm{MMR}_{\mathrm{s}}$ for $59 \%$ of measurements. This indicates that the chase protocol of 5 min (consisting of 1 min chase, 3 min turning fish over, and 1 min air exposure) was insufficient to obtain maximum metabolic rates that were higher than the spontaneous rates observed in the chambers during a $24 \mathrm{~h}$ observation period. While critical swimming speed trials can also be used to obtain MMR, chase protocols are widely used as well and give similar results to swim trials [45]. In another study, swim trials were found to reveal the highest MMR estimates, with chase trials reflecting 36\% lower MMR than swim trials, and only $23 \%$ lower when an air exposure element was added to the chase trial [36]. Therefore, the recommendations of these authors were followed to use a chase with an air exposure element, as swim trials were not possible in the current study. The results of the current study support the idea that chase trials may not obtain true $M M R$ (as our $\mathrm{MMR}_{\mathrm{s}}$ were higher than $\mathrm{MMR}_{\mathrm{f}}$ in most cases).

This article is protected by copyright. All rights reserved 
While $\mathrm{MMR}_{\mathrm{s}}$ is less often used as a metabolic metric than $\mathrm{MMR}_{\mathrm{f}}$, it has been used in other studies and there is evidence that it is perhaps more ecologically relevant than $\mathrm{MMR}_{\mathrm{f}}$ as a measure of exhaustive energy expenditure [31]. Animals may not exercise at maximal intensity very often under natural conditions and spontaneous maximal performance is likely a better reflection of peak metabolic expenditure in natural settings, and therefore, how it may be influenced by stressors such as nAg exposures [46].

In this study, $\mathrm{MMR}_{\mathrm{s}}$ was usually caused by light disturbances in the room. The effect of light changes on metabolic rates has been observed before, and because of this many studies expose fish to only dim lighting during respirometric trials, or otherwise shield fish from large changes in light intensity [29, 33, 40]. This was not done in this study; fish were exposed to the same lighting regime as they were throughout the $28 \mathrm{~d}$ exposure trials. This lighting regime employed gradual light changes, similar to light increases in nature during sunrise and sunset, but appears to have still been sufficient to elicit a metabolic reaction in fish in the form of peak activity. It is also possible that this observation simply reflects natural patterns of metabolic expenditure, since fish are traditionally known to be most active during the crepuscular periods of sunrise and sunset [47].

$\mathrm{MMR}_{\mathrm{f}}$ was approximately $21 \%$ higher when fish were chased before the SMR experiments, likely due to the increased stress fish were experiencing from being in the new environment of the respirometric chambers, combined with exercise stress when the chase protocol was conducted. This suggests that in general, it may be beneficial to conduct chase protocols prior to SMR trials, to increase the maximum metabolic rate estimate that is achieved. Conducting chase protocols was also found to decrease SMR measurements by approximately $20 \%$. The reason for this difference is unknown, as it was expected that the timing of the chase

This article is protected by copyright. All rights reserved 
protocol would either have no effect or potentially increase SMR if done before (due to excess post-exercise oxygen consumption $[48,49])$. Potentially this effect was seen due to fish that were chased beforehand being forced into a more 'active coping style' towards stress, in that fish that are known to have 'active' coping styles (have a more active response to stress - measured by having a higher number of escape attempts from a stressor, and a lower latency period of the first escape attempt) have been found to have lower SMRs than fish with 'passive' coping styles [50]. Individuals who react actively to stress may 'evacuate' their stress more effectively and therefore generate lower estimates of SMR [51]. However, additional research is needed to draw solid conclusions, as forcing a fish to swim in a chase trial as was done in this study may not be equivalent to the inborn personality traits of fish. Regardless, any differences within this study were accounted for in analysis through inclusion of the "before-after" variable in the mixedmodel analysis used.

Respirometric results from this study suggest that care must be taken when using chase trials to obtain MMR estimates, as they may result in MMR estimates that are lower than the actual maximum rate. In addition conducting chase trials before respirometric trials appears to provide benefits to estimating both $\mathrm{MMR}_{\mathrm{f}}$ and $\mathrm{SMR}$ [44]. This is useful information as conducting chase trials before is more efficient and results in less handling of fish, however with this method there has been concerns that the recovery period from the chase may increase SMR estimates [35]. The present results indicate that SMR estimates are not affected detrimentally, and consequently the chase can be performed beforehand.

This study presents information on $\mathrm{nAg}$ exposure that will be helpful to regulators and ongoing whole-ecosystem experiments by demonstrating that the metabolic effects of $\mathrm{nAg}$ at environmentally-relevant concentrations were undetectable over a significant (28 d) exposure

This article is protected by copyright. All rights reserved 
period. Overall, the effects of $\mathrm{nAg}$ exposure to $O$. mykiss metabolism were absent, or at best, only marginal in our study, and only at the highest exposure concentrations, despite the observation of elevated plasma cortisol concentrations and Ag accumulation in muscle due to nAg exposure in a companion study [23]. While adaptation to contaminant exposure has been suggested in other studies [13], it is unlikely that this was entirely the case in this study, where fish exposed to $\mathrm{nAg}$ were found to have elevated stress (indicated by higher blood cortisol concentrations) throughout the study. This information will provide valuable context when evaluating changes in energetics and growth of fishes exposed to nAg in the environment. Supplemental Data - The Supplemental Data are available on the Wiley Online Library at DOI: 10.1002/etc.xxxx.

Acknowledgment-Funding for this research was provided by the Natural Sciences and Engineering Research Council of Canada, the Experimental Lakes Area, the University of Manitoba Faculty of Science, and Fish Futures Inc. Thanks to K. Wautier, C. Rodgers, A. Chapelsky, and C. Kyle-Ottenson at Fisheries and Oceans Canada and E. Sotiri at the University of Manitoba for their technical assistance to the project.

Data Availability—Data can be accessed by contacting the author (lamurray12@gmail.com ).

This article is protected by copyright. All rights reserved 


\section{REFERENCES}

1. Wijnhoven SWP, Peijnenburg WJGM, Herberts CA, Hagens WI, Oomen AG, Heugens EHW, Roszek B, Bisschops J, Gosens I, Van De Meent D. 2009. Nano-silver - a review of available data and knowledge gaps in human and environmental risk assessment. Nanotoxicology 3:109-138.

2. Pulit-Prociak J, Stokłosa K, Banach M. 2014. Nanosilver products and toxicity. Environ Chem Let 13:59-68.

3. Choi O, Clevenger TE, Deng B, Surampalli RY, Ross L, Hu Z. 2009. Role of sulfide and ligand strength in controlling nanosilver toxicity. Water Res 43:1879-1886.

4. Gottschalk F, Sun TY, Nowack B. 2013. Environmental concentrations of engineered nanomaterials: Review of modeling and analytical studies. Environ Pollut 181:287-300.

5. Sun TY, Gottschalk F, Hungerbühler K, Nowack B. 2014. Comprehensive probabilistic modeling of environmental emissions of engineered nanomaterials. Environ Pollut 185:69-76.

6. Blaser S, Scheringer M, Macleod M, Hungerbühler K. 2008. Estimation of cumulative aquatic exposure and risk due to silver: contribution of nano-functionalized plastics and textiles. Sci Total Environ 390:396-409.

7. Liu J, Chao J, Liu R, Tan Z, Yin Y, Wu Y. 2009. Cloud point extraction as an advantageous preconcentration approach for analysis of trace silver nanoparticles in environmental waters. Anal Chem 81:6496-6502.

8. Lapresta-Fernández A, Fernández A, Blasco J. 2012. Nanoecotoxicity effects of engineered silver and gold nanoparticles in aquatic organisms. TrAC 32:40-59.

This article is protected by copyright. All rights reserved 
9. Farkas J, Christian P, Urrea JAG, Roos N, Hassellöv M, Tollefsen KE, Thomas KV. 2010. Effects of silver and gold nanoparticles on rainbow trout (Oncorhynchus mykiss) hepatocytes. Aquat Toxicol 96:44-52.

10. Bilberg K, Malte H, Wang T, Baatrup E. 2010. Silver nanoparticles and silver nitrate cause respiratory stress in Eurasian perch (Perca fluviatilis). Aquat Toxicol 96:159-165.

11. Farmen E, Mikkelsen HN, Evensen O, Einset J, Heier LS, Rosseland BO, Salbu B, Tollefsen KE, Oughton DH. 2012. Acute and sub-lethal effects in juvenile Atlantic salmon exposed to low $\mu \mathrm{g} / \mathrm{L}$ concentrations of Ag nanoparticles. Aquat Toxicol 108:7884.

12. Pham CH, Yi J, Gu MB. 2012. Biomarker gene response in male Medaka (Oryzias latipes) chronically exposed to silver nanoparticle. Ecotoxicol Environ Safety 78:239_ 245.

13. Griffitt RJ, Brown-Peterson NJ, Savin DA, Manning CS, Boube I, Ryan RA, Brouwer M. 2012. Effects of chronic nanoparticulate silver exposure to adult and juvenile sheepshead minnows (Cyprinodon variegatus). Environ Toxicol Chem 31:160-167.

14. Rennie MD, Collins NC, Shuter BJ, Rajotte JW, Couture P. 2005. A comparison of methods for estimating activity costs of wild fish populations: more active fish observed to grow slower. Can J Fish Aquat Sci 62:767-780.

15. Rennie MD, Purchase CF, Shuter BJ, Collins NC, Abrams PA, Morgan GE. 2010. Prey life-history and bioenergetic responses across a predation gradient. J Fish Biol 77:12301251.

This article is protected by copyright. All rights reserved 
16. Djawdan M, Sugiyama TT, Schlaeger LK, Bradley TJ, Rose MR. 1996. Metabolic aspects of the trade-off between fecundity and longevity in Drosophila melanogaster. Physiol Zool 69:1176-1195.

17. Speakman JR. 2005. Body size, energy metabolism and lifespan. J exp Biol 208:17171730.

18. Handy RD, Depledge MH. 1999. Physiological responses: their measurement and use as environmental biomarkers in ecotoxicology. Ecotoxicol Environ Safety 8:329-349.

19. McKenzie DJ, Garofalo E, Winter MJ, Ceradini S, Verweij F, Day N, Hayes R, van der Oost R, Butler PJ, Chipman JK. 2007. Complex physiological traits as biomarkers of the sub-lethal toxicological effects of pollutant exposure in fishes. Philos Trans $R$ Soc Lond B Biol Sci B 362:2043-2059.

20. Sokolova I, Lannig G. 2008. Interactive effects of metal pollution and temperature on metabolism in aquatic ectotherms: implications of global climate change. Clim Res $37: 181-201$.

21. Norin T, Malte H. 2012. Intraspecific variation in aerobic metabolic rate of fish: relations with organ size and enzyme activity in brown trout. Physiol Biochem Zool 85:645-656.

22. Fry FEJ. 1947. Effects of the environment on animal activity. University of Toronto Studies, Biological Services, no. 55. Publ. Ontario Fish. Res. Lab. 68:1-62.

23. Murray, LM, Rennie, MD, Enders, EC, Pleskach, K, Martin, JD. 2017. Effect of nanosilver on cortisol release and morphometrics in rainbow trout (Oncorhynchus mykiss). Environ Toxicol Chem. in press. doi: 10.1002/etc.3691.

24. Murray L. 2015. Effect of nanosilver particles on metabolism and cortisol release in rainbow trout (Oncorhynchus mykiss). Master's thesis. University of Manitoba.

This article is protected by copyright. All rights reserved 
25. Steffensen, JF. 1989. Some errors in respirometry of aquatic breathers: how to avoid and correct for them. Fish Physiology and Biochemistry. 6(1): 49-59.

26. Rosewarne, PJ, Wilson, JM, Svendsen, JC. 2016. Measuring maximum and standard metabolic rates using intermittent-flow respirometry: a student laboratory investigation of aerobic metabolic scope and environmental hypoxia in aquatic breathers. J Fish Biol. 88:265-283. doi:10.1111/jfb.12795.

27. Svendsen, JC, Banet, AI, Christensen, RHB, Steffensen, JF, Aarestrup, K. 2013. Effects of intraspecific variation in reproductive traits, pectoral fin use and burst swimming on metabolic rates and swimming performance in the Trinidadian guppy (Poecilia reticiulata). J Exp Biol. 216:3564-3574. doi:10.1242/jeb.083089.

28. Norin T, Malte H. 2011. Repeatability of standard metabolic rate, active metabolic rate and aerobic scope in young brown trout during a period of moderate food availability. $J$ Exp Biol 214:1668-1675.

29. Tang M, Boisclar D, Mènard C, Downing J. 2000. Influence of body weight, swimming characteristics, and water temperature on the cost of swimming in brook trout (Salvelinus fontinalis). Can J Fish Aquat Sci 57:1482-1488.

30. Schurmann, H. Steffensen, JF. 1997. Effects of temperature, hypoxia and activity on the metabolism of juvenile Atlantic cod. J Fish Biol. 50:1166-1180.

31. Svendsen JC, Genz J, Anderson GW, Stol JA, Watkinson DA, Enders EC. 2014. Evidence of circadian rhythm, oxygen regulation capacity, metabolic repeatability and positive correlations between forced and spontaneous maximal metabolic rates in lake sturgeon Acipenser fulvescens. PLoS One 9:e94693.

This article is protected by copyright. All rights reserved 
32. Chabot D. Steffensen JF. Farrell AP. 2016. The determination of standard metabolic rate in fishes. J Fish Biol. 88:81-121. doi:10.1111/jfb.12845.

33. Svendsen JC, Steffensen JF, Aarestrup K, Frisk M, Etzerodt A, Jyde M. 2012. Excess posthypoxic oxygen consumption in rainbow trout (Oncorhynchus mykiss): recovery in normoxia and hypoxia. Can J Zool 11:1-11.

34. Clark TD, Sandblom E, Jutfelt F. 2013. Aerobic scope measurements of fishes in an era of climate change: respirometry, relevance and recommendations. J Exp Biol 216:27712782.

35. Norin T., Clark TD. 2016. Measurement and relevance of maximum metabolic rate in fishes. J Fish Biol. 88(1):122-51. doi:10.1111/jfb.12796.

36. Roche DG, Binning SA, Bosiger Y, Johansen JL, Rummer JL. 2013. Finding the best estimates of metabolic rates in a coral reef fish. J Exp Biol 216:2103-2110.

37. Milligan CL. 1996. Metabolic recovery from exhaustive exercise in Rainbow trout. Comp Biochem Physiol A 113:51-60.

38. R Core Team. 2015. R: A language and environment for statistical computing. $\mathrm{R}$ Foundation for Statistical Computing V, Austria. URL http://www.R-project.org/.

39. Cowart DA, Guida SM, Shah SI, Marsh AG. 2011. Effects of Ag nanoparticles on survival and oxygen consumption of zebra fish embryos, Danio rerio. J Environ Sci Health [A] 46:1122-1128.

40. Morgan JD, Iwama GK. 1996. Cortisol-induced changes in oxygen consumption and ionic regulation in coastal cutthroat trout (Oncorhynchus clarki clarki) parr. Fish Physiol Biochem 15:385-394.

This article is protected by copyright. All rights reserved 
41. O'Connor CM, Gilmour KM, Arlinghaus R, Matsumura S, Suski CD, Philipp DP, Cooke SJ. 2011. The consequences of short-term cortisol elevation on individual physiology and growth rate in wild largemouth bass (Micropterus salmoides). Can J Fish Aquat Sci 68:693-705.

42. Mager EM, Grosell M. 2011. Effects of acute and chronic waterborne lead exposure on the swimming performance and aerobic scope of fathead minnows (Pimephales promelas). Comp Biochem Physiol C 157:7-13.

43. Wilson RW, Bergman HL, Wood CM. 1994. Metabolic costs and physiological consequences of acclimation to aluminum in juvenile Rainbow trout (Oncorhynchus mykiss). 2: gill morphology, swimming performance, and aerobic scope. Can J Fish Aquat Sci 51:536-544.

44. Murray L, Rennie MD, Svendsen JC, Enders EC. in press. Effects of respirometry methods on cortisol release in rainbow trout Oncorhynchus mykiss. J Fish Biol.

45. Cutts CJ, Metcalfe NB, Taylor AC. 2002. Juvenile Atlantic salmon (Salmo salar) with relatively high standard metabolic rates have small metabolic scopes. Funct Ecol 16:7378.

46. Husak JF. 2006. Does survival depend on how fast you can run or how fast you do run? Funct Ecol 20:1080-1086.

47. Helfman GS. 1981. Twilight activities and temporal structure in a freshwater fish community. Can J Fish Aquat Sci 38:1405-1420.

48. Lee CG, Farrell, AP, Lotto, A, Hinch, SG, Healey, MC. 2003. Excess post-exercise oxygen consumption in adult sockeye (Oncorhynchus nerka) and coho (O. kisutch)

This article is protected by copyright. All rights reserved 
salmon following critical speed swimming. J Exp Biol. 206: 3253 - 3260.

doi:10.1242/jeb.00548.

49. Norin, T. Clark, TD. 2016. Measurement and relevance of maximum metabolic rate in fishes. J Fish Biol. 88(1): 122-151. doi:10.1111/jfb.12796.

50. Martins CIM, Castanheira MF, Engrola S, Costas B, Conceicao LEC. 2011. Individual differences in metabolism predict coping styles in fish. Appl Anim Behav Sci 130:135143.

51. Careau V, Thomas D, Humphries MM, Reale D. 2008. Energy metabolism and animal personality. Oikos 117:641-653.

Figure 1. Metabolic variables for different treatment $(\mathrm{T})$ levels $(\mathrm{C}=$ control, $\mathrm{L}=$ low $\quad(0.28 \pm$ 0.02), and $\mathrm{H}=$ high $(47.61 \pm 5.13)$. Data expressed as means \pm standard errors. (A) Standard metabolic rate $(\mathrm{SMR}),(\mathrm{B})$ Forced maximal metabolic rate $\left(\mathrm{MMR}_{\mathrm{f}}\right),(\mathrm{C})$ Spontaneous maximum metabolic rate $\left(\mathrm{MMR}_{\mathrm{s}}\right)$, (D) Forced Aerobic Scope $\left(\mathrm{AS}_{\mathrm{f}}\right)$, and (E) Spontaneous Aerobic Scope $\left(\mathrm{AS}_{\mathrm{s}}\right)$

Figure 2. SMR experiment for a typical fish in the respirometric trials, showing $\dot{M} \mathrm{O}_{2}$ over $24 \mathrm{~h}$. Timing of changes in lighting (lights turned off at 20:00 $\mathrm{h}$ and on at 08:00 h) are marked with hashed lines.

Figure 3. Differences in metabolic variables by timing of $M M R_{f}$ procedure (before or after SMR experiment). (A) Forced maximum metabolic rate $\left(\mathrm{MMR}_{\mathrm{f}}\right),(\mathrm{B})$ Forced aerobic scope $\left(A S_{\mathrm{f}}\right)$, and (C) Standard metabolic rate (SMR). Asterisks denote significant differences between groups $(*=$ $p<0.05, * *=p<0.001)$.

This article is protected by copyright. All rights reserved 


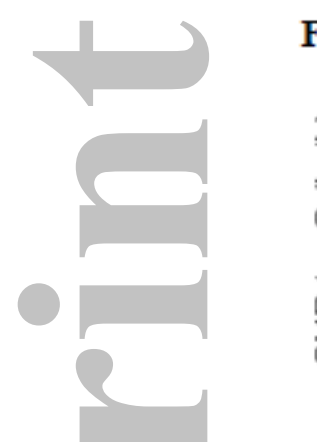

\section{Figure 1}
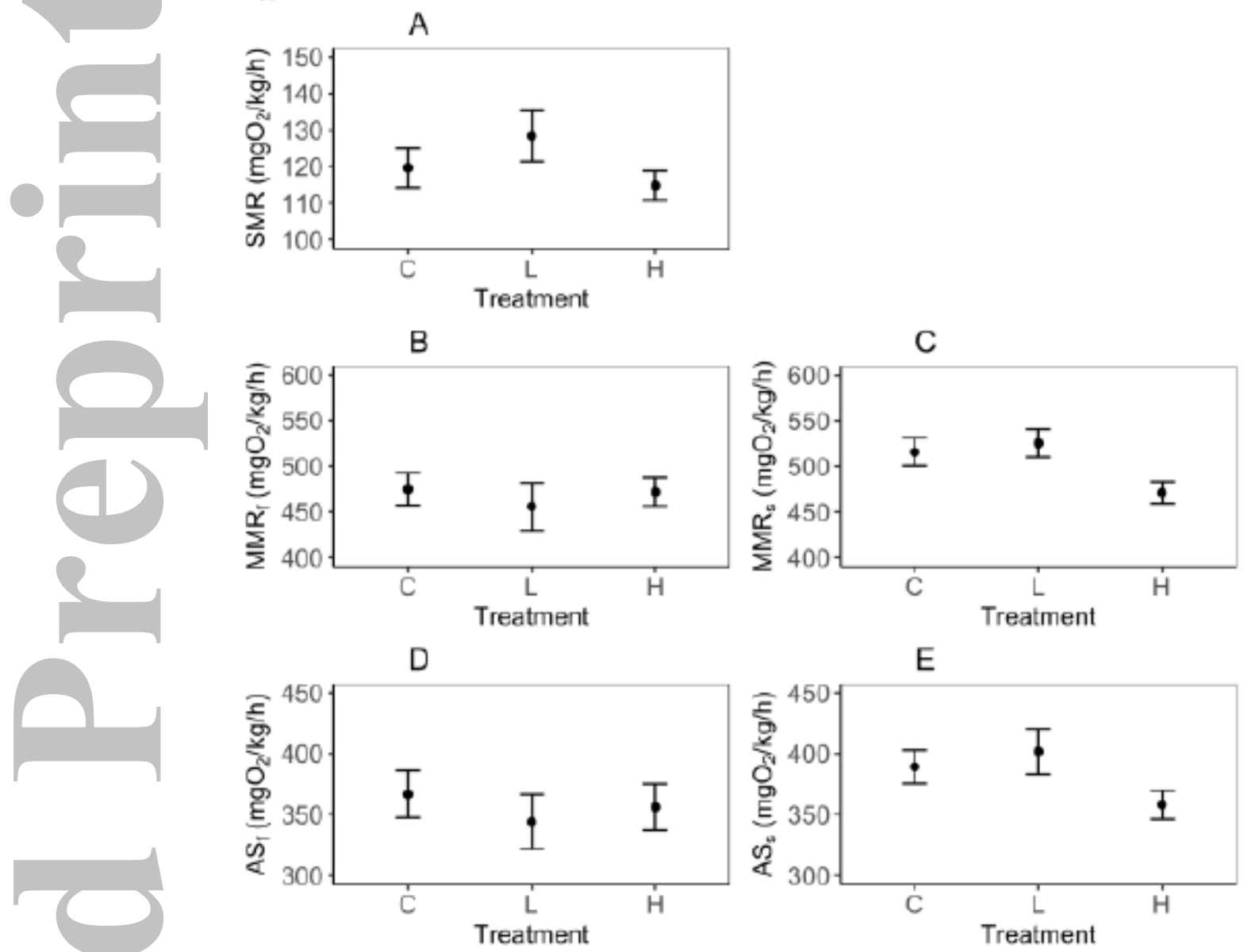

This article is protected by copyright. All rights reserved 
Figure 2

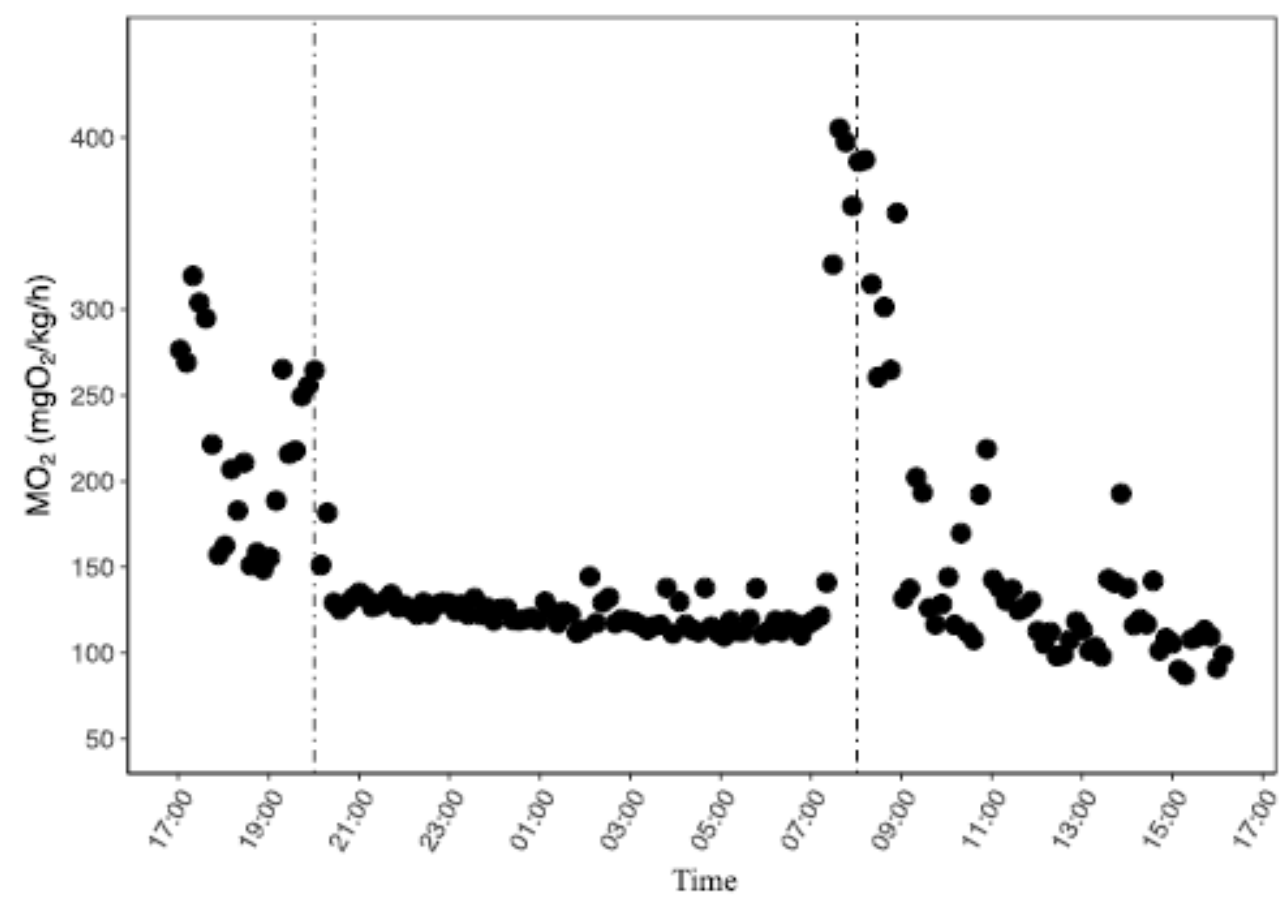

This article is protected by copyright. All rights reserved 


\section{Figure 3}
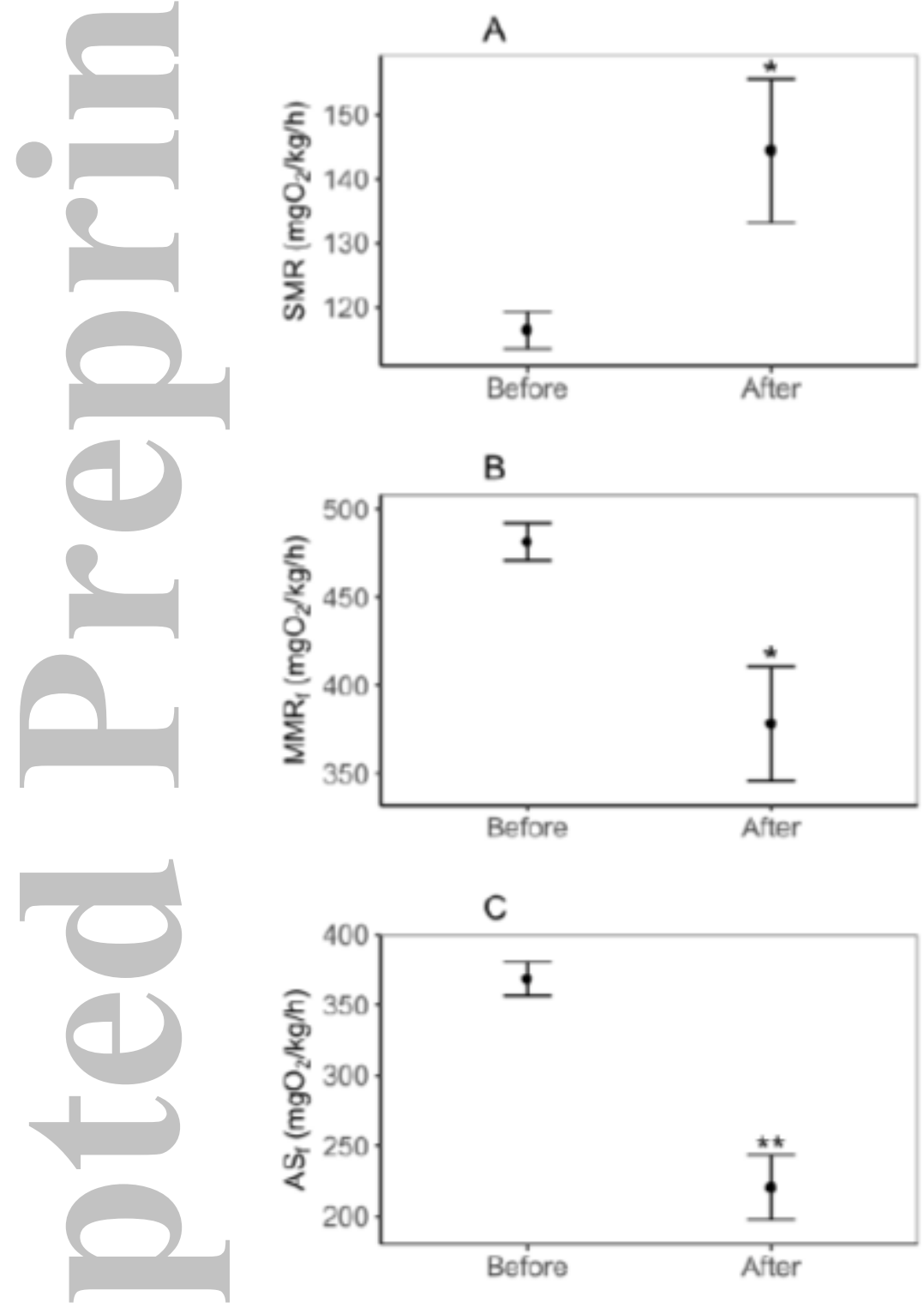

This article is protected by copyright. All rights reserved 
Table 1. Mean, standard error, and samples sizes (n) for metabolic variables in different $\mathrm{nAg}$ exposure treatments. Values of metabolic variables are in $\mathrm{mgO}_{2} / \mathrm{kg} / \mathrm{h}$.

\begin{tabular}{|l|cc|cc|cc|cc|cc|}
$\begin{array}{l}\text { Exposure } \\
\text { Levels }\end{array}$ & $\begin{array}{c}\text { SMR } \\
\text { mean } \pm \text { S. E. }\end{array}$ & $\mathbf{n}$ & $\begin{array}{r}\text { MMR } \\
\text { mean } \pm \text { S. E. }\end{array}$ & $\mathbf{n}$ & $\begin{array}{r}\text { MMRs } \\
\text { mean } \pm \text { S. E. }\end{array}$ & $\mathbf{n}$ & $\begin{array}{c}\text { AS } \\
\text { mean } \pm \text { S. E. }\end{array}$ & n & ASean \pm S. E. & $\mathbf{n}$ \\
\hline Control & $119.66 \pm 5.33$ & 25 & $474.82 \pm 17.58$ & 31 & $515.79 \pm 15.26$ & 29 & $366.70 \pm 19.31$ & 25 & $389.17 \pm 13.82$ & 25 \\
Low & $128.35 \pm 6.95$ & 15 & $455.88 \pm 26.06$ & 15 & $525.43 \pm 14.94$ & 15 & $344.06 \pm 22.30$ & 14 & $401.79 \pm 18.59$ & 15 \\
High & $114.84 \pm 3.97$ & 40 & $471.92 \pm 15.52$ & 47 & $471.36 \pm 12.12$ & 45 & $356.04 \pm 19.02$ & 40 & $358.05 \pm 11.82$ & 40 \\
Overall & $118.88 \pm 2.91$ & 80 & $470.25 \pm 10.57$ & 93 & $494.95 \pm 8.59$ & 89 & $357.29 \pm 11.97$ & 79 & $375.65 \pm 8.28$ & 80 \\
\hline
\end{tabular}

This article is protected by copyright. All rights reserved 